\title{
The Role of Financial Intermediaries in Capital Market
}

\author{
Mahdi Salehi*
}

\begin{abstract}
In the recent years, a growing of theoretical and empirical literature has developed a paradigm in which the extent of financial intermediation and the rate of economic growth are endogenously determined. Financial intermediaries emerge to reduce the information asymmetries, extending corporate control, risk management and mobilizing saving. In this paper the authors came to conclusion that although the Iranian financial intermediaries play very important role in economic, it is not much sufficient. It should be also provided foreign financial intermediaries for practicing in Iranian business sectors.
\end{abstract}

Keywords: financial institution, financial intermediaries, firm performance, Iran

JEL Classification: G200

\section{Introduction}

Do economies with higher levels of financial intermediary development experience more or less volatility in economic growth rates? Do intermediaries dampen the impact of external shocks on the economy or do they amplify them through the credit channel? While the recent empirical and theoretical literature has established a positive impact of financial sector development on economic growth, the potential links between financial development and the volatility of economic growth have not been studied still, the high growth volatility that many developing countries thoroughly yet.

Experience has brought to the forefront the question whether and to what extent output fluctuations can be related to the development of the financial sector. Explaining the determinants of growth volatility is important for policy makers who want to secure a high and stable growth rate for their economies.

In view of the above fact, there is a positive relationship between the finance sector development and economic growth. Finance sector may be sub-divided into several

\footnotetext{
* Mahdi Salehi is at Zanjan University, Zanjan, Iran.
} 
factors of which, one of the most important factors of the finance sector is intermediaries. Financial intermediation involves banks and other institutional investors playing pivotal roles in transforming savings into investment, thereby facilitating liquidity, information, and consumption smoothing. Financial intermediaries also serve as a commitment mechanism and provide delegated monitoring to the organization to which they provide capital. Traditionally, transaction costs and asymmetric information have provided the foundation for understanding intermediaries. Financial intermediaries have also played a pivotal role in the growth of the real sector in the development experience of the developed and newly industrialized countries (Goldsmith 1969, Patrick 1966).

To ask the question why most lending/borrowing takes place through a financial intermediary is to also ask the question why financial intermediaries exist. There are three main reasons why financial intermediaries exist:

1. Different requirements of lenders and borrowers;

2. Transaction costs, and

3. Problems arising out of information asymmetries.

In this paper the authors assumed that the existence of financial intermediaries has effect on financial firm performance, therefore it also effects on economic growth.

The primary objective of this paper is to determine the link between financial intermediation and firm financial performance in Iran. The remainder of this paper organized as follows role of financial intermediaries, review of empirical studies, analyses and conclusion.

\section{Role of Financial Intermediaries}

Numerous theoretical models show that economic agents may form financial intermediaries to mitigate the costs of acquiring information and conducting transactions. More specifically, financial intermediaries emerge to lower the costs of researching potential investments, exerting corporate control, managing risk, and mobilizing savings. It is safe to say that, by providing these services to the economy, financial intermediaries influence savings and allocation decisions in ways that may alter long-run growth rates. Thus, modern economic theory provides an intellectual framework or understanding how, ceteris paribus, countries with 'better' financial intermediaries; financial intermediaries that are better at acquiring information, exerting corporate control, managing risk, and mobilizing savings, would grow faster than countries with less developed financial systems. 
Developments in modern financial theory offer an enhanced understanding of the conditions under which investors, intermediaries and users of funds tend to prefer fixed-return debt contracts. Further, these theories provide ample support for the establishment of a system that operates on an equity basis instead of a predetermined interest rate. In addition, the financial system is a key factor when it comes to explaining and understanding the development of the world's economy. The creation of money as a means of exchange and the increasing need of people to find an efficient and beneficial way to trade their assets, and more importantly to take advantage of the great monetary value attached to them has caused the appearance of specific institutions, markets and individuals that provide the appropriate environment to perform these activities. The evolution of this system is therefore, the result of lenders and borrowers wishing to make the most out of their situation. With this purpose, funds are to be efficiently transferred between deficit and surplus units that are brought together in order to achieve higher production and efficiency for the economy as a whole. The channeling of funds between the two groups mentioned can only happen accurately in the presence of particular participants and via main routes such as financial intermediaries or through the use of organized financial markets. It is important to analyze the way not only lenders and savers but also financial intermediaries benefit from this situation. Mishkin and Eakins (2006) discuss that financial intermediaries can substantially reduce transaction costs that can be defined as the time and money spent in performing financial transactions, for instance the exchange of assets, goods or services. Because of their large size and expertise, they are able to take advantage of economies of scale. The low transaction costs allow these institutions to offer liquidity services as it is simpler to sell financial instruments to raise cash. In addition, financial intermediaries are able to greatly reduce the exposure to potential risks by sharing the risks among various investors and consequently achieving significant diversification due to the large and varied volume of resources they deal with. In this way, they virtually turn risky assets into safer ones for the benefit of investors and for theirs as well as they gain profits on the difference between the returns and the payments they make. Another important reason why financial intermediaries play such a significant role in the financial system is because of the inequality of information available between parties. Asymmetric information is fundamental to understanding the need for regulation as it affects the sense of balance that any market needs to remain in a stable situation. Its presence makes it difficult to tell whether the terms of the transactions being held between parties are mutually satisfying and therefore, jeopardize the solidity of market conditions. Allegedly, financial intermediaries are able to lessen these problems. The reason is that because of the financial involvement in the intermediation process, they are able to screen out bad risks and monitor the utilization of the loans provided. Nonetheless, this feature has not always proven to 
be correct. It is evident that financial intermediaries play a key role in improving the performance of the economy and are therefore successful elements of the financial system. Financial markets and institutions embody a mixture of specific elements that are brought together with the sole purpose of controlling and coping with the enormous amount of assets available and the income generated by them.

\section{Financial Intermediaries Feature}

The concept of good financial system has received considerable attention in literature on finance sector and economic development (Mowery, 1998). It is safe to say that the financial institutions, because of several reasons, play more important role in a well developing economy. The theoretical underpinnings of the relationship between financial development and growth can be traced back to the work of Schumpeter (1912) and, later, Goldsmith (1969), McKinnon (1973), and Shaw (1973). While Gurley and Shaw (1960) describe financial innovation, the link between financial development and economic growth has been analyzed within the framework of a wide array of endogenous growth models (Greenwald and Stiglitz, 1989; Greenwood and Jovanovic, 1990; Levine, 1991; Bencivenga and Smith, 1991, 1992, 1993; Saint-Paul, 1992, 1997Atje and Jovanovic, 1993; Berthelemy and Varoudakis, 1995, 1997; Carranza, 2000, Khan and Senhadji, 2000; and Tsuru, 2000). The existence of financial intermediaries is based on the potential economies of scale in banking, which amongst other things can result in risk-reduction (via diversification) and maturity transformation. The incentive explanation is based on the existence of information/transaction costs and incomplete contracts. Hence, economic agents form financial intermediaries to mitigate market frictions and reduce transaction costs. Lower transaction costs induce a greater number of transactions thus allowing for more specialization. The below given chart shows the major parts of financial institutions (figure 1).

Moreover, it is costly for individuals to acquire information and to evaluate and monitor firms and their managers. Since financial intermediaries can economize on the costs of acquiring information they have an advantage over individuals and non-specialized entities to intermediate between borrowers and lenders. Therefore, financial intermediaries can contribute to economic growth by facilitating the exchange process, monitoring performance of firms, and due to their information acquisition capabilities improve resource allocation in the credit market. 
Figure 1: Feature of financial institution

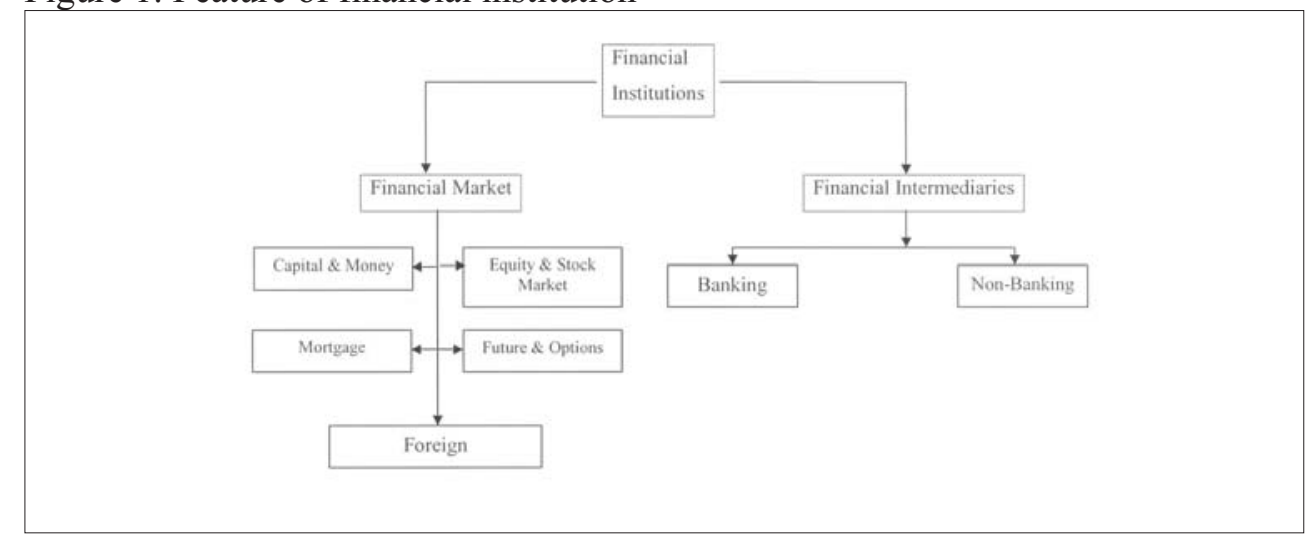

There are financial intermediaries that are subject to general specific of regulation and supervision; their programes, activities and transactions are regulated and overseen by the Central Bank in so many countries. These include commercial and governmental banks, savings and also cooperative and private financial institutions, which are officially registered under formal legislation. Below given figure highlights the major constituents of financial intermediaries. The types of intermediaries are shown in figure 2.

Figure 2: Components of financial intermediaries

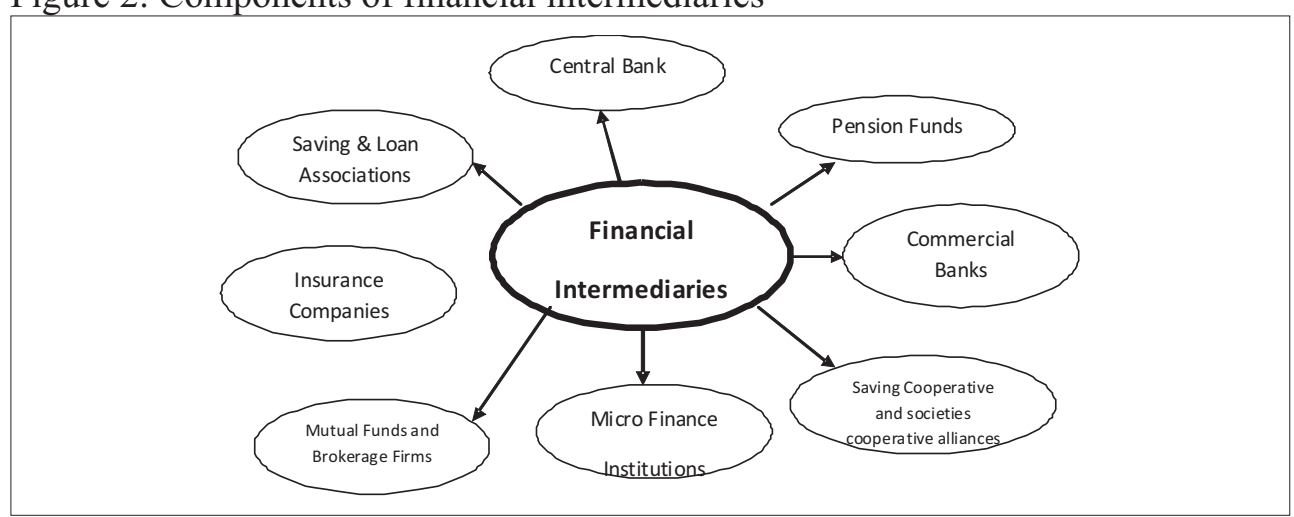

Financial intermediaries emerge to reduce those asymmetries and lower the costs of researching potential investments, exerting corporate control, managing risk, and mobilizing savings. Therefore, countries with superior financial systems will, ceteris paribus, allocate savings to more efficient and productive endeavors and will grow faster than countries with less effective financial systems. In the era of globalization, the potential contribution of financial development to the acceleration of growth is 
further financial intermediaries have an advantage in gathering information on investment projects and hence allocate the funds to high-return investments and can positively affect growth (Berthelemy and Varoudakis 1996). Intermediaries collect information on alternative projects and invest the funds in projects that yield highest returns. The process of growth also stimulates higher participation in financial markets and their expansion. The intuition is that financial intermediaries provide liquidity to individuals that face an uncertain future liquidity need. The individuals can invest in a liquid asset with a low risk and low productivity or in an asset with liquidity risks and higher productivity. The law of large numbers creates a more predictable liquidity demand for banks (Bencivenga and Smith, 1991). In the presence of financial intermediation the individuals are not forced to liquidate illiquid investment when the need for liquidity arises. Therefore, financial intermediaries tend to alter the composition of savings in a way that induces more investment in high productivity assets and in this way they promote long-run growth in an endogenous growth model setting.

\section{Review of Literature}

There are only a few researchers regarding the effect of financial intermediaries on firm performance. Majority of researchers have conducted research on financial intermediaries on economic growth. One of the primary roles of financial intermediaries is to facilitate the provision of liquidity. Financial intermediation involves banks borrowing from a large number of agents through deposit contracts, and providing a large number of consumers and firms with liquidity. In general terms, financial intermediaries reduce the costs of search for borrowers and lenders, and facilitate the ability to trade at low transaction costs (Harris, 2003; Kyle, 1985). Given the position of intermediary, banks have a related function as information providers because their role provides access to detailed information not widely available.

Seminal work on information by Leland and Pyle (1977; Diamond, 1984) shows that the information gathered by a financial intermediary can be protected (i.e., the intermediary can overcome an 'appropriation problem') and can be credibly ensured to be reliable (i.e., the intermediary can overcome a 'reliability problem') by issuing securities and using the proceeds to invest in companies in which the intermediary has favorable private information. To this end, financial intermediaries have incentives to invest in the acquisition of private information pertaining to investee companies, which in turn enhances the profitability of the financial intermediary.

Financial intermediaries perform the roles of resource mobilization and allocation, risk diversification and liquidity management to foster development of the 
real sector. Gurley and Shaw (1960) argue that one of the primary functions of financial intermediaries is to transform illiquid liabilities issued by the corporate sector into more liquid instruments held by consumers. Even before that Edgeworth (1888) suggested that, because of diversification in the pool of depositors, financial intermediaries are efficient providers of liquid assets. In a complete information deterministic world also, financial intermediaries can have the important role of a temporary resource provider when there is a time lag between the firms' factor payments and receipts from sale proceeds (Edwards and Vegh 1998, Buffie 1986). This role assumes greater significance when the firms do not have enough internal resources to cover its factor payments and the financial intermediaries come in with working capital finance. In the process of financial development equity markets across the world have become another important source of resource mobilization and allocation. Equity markets are fast catching up with traditional financial intermediaries in terms of volume and transactions (Boyd and Smith 1998). Atje and Jovanovic (1993), Harris et. al. (1994) and Levine and Zervos (1998) present cross-country studies of equity market development and economic growth to show that they are highly correlated. Generally financing through the equity market has been observed to be relatively long term in nature as compared to the traditional intermediaries. The penchant for intermediaries towards short-term loans can be interpreted as a preference towards financing the variable cost needs of the firms. On the other hand firms tend to approach the equity markets to finance their fixed cost needs. Differentiation along these lines is consistent with the conclusion of Levine and Zervos (1998) that 'both stock markets and banks arise and develop simultaneously while providing different bundles of financial services to the economy.'

Greenwood and Javanovic (1990), point out the role of financial intermediaries as selectors of investment projects, the selection of more profitable projects resulting from the evaluation of the more favorable risk/return project rates. The existence of specific selection criteria theoretically originates a better allocation of financial resources in an economy. Allen and Ndikumana (1998) used various indicators of financial development to investigate the role of financial intermediation stimulating firm performance and economic growth. They found that financial intermediation performance is positively related to firm performance and economic growth.

As stated by Levine (1997, 1999), financial intermediaries have the capacity of reducing the information gathering costs associated to the development of investment projects. A reduced number of financial intermediaries can therefore collect the necessary information to implement and develop new investment projects. Otherwise, each investor, individual or institution, would have to invest primarily in gathering its necessary information, which would be a more costly and time-consuming process. 
Currently, There is considerable pent-up demand for financial services in Iran. Most notably, the failings of the Iranian banking system make it difficult for private enterprises and individuals to access affordable credit, forcing them to turn to unregulated or poorly regulated lenders. Nor do the banks offer a plausible medium for saving, offering unattractive deposit rates. This has fuelled real estate inflation. Concerns about regulation and transparency on the Tehran Stock Exchange (TSE) also constrain demand, and the bourse remains dominated by state entities. State domination of the insurance industry has led to poor service and outmoded, inflexible products.

\section{Methodology}

Since the main objective of this study was to find the effect of consulate with financial intermediaries on financial structure of Iranian companies, we designed and developed a questionnaire for finding this effect. The measure instrument of the questions is a five-point's likert type scale anchored 'very less' (1) and 'very much' (5). Fifteen questions for each hypothesis assumed five questions; questions 1-5 related to the first hypothesis, questions 6-10 related to second hypothesis and questions 11-15 related to third hypothesis.

We selected 83 manufacturing firms listed in Tehran Stock Exchange. To prevent bias in selection, these firms were selected randomly. Then, we sent questionnaires to firms' managers. 67 answered papers were returned. To analyze data, we employed 'Chi-Square test for comparing the frequency of observed samples and expected frequency.

\section{Hypotheses of the Study}

In carrying out the study, the following hypotheses were identified:

i) The consulting with financial intermediaries associate to financial structure of quoted firms in Tehran Stock Exchange;

ii) The effectiveness role of financial management associate to increase share value of quoted firms in Tehran Stock Exchange; and

iii) Intermediaries' financial expert associate to decrease investment risk.

Results: An important objective of any financial system is to mobilize aggregate savings and channel it towards investment in productive enterprise. If capital is not mobile, economic development may be retarded because funds are not channeled 
from surplus to deficit regions and sectors. In these conditions the financial intermediaries play very vital role in any economy as well as in Iran which we assume a developing country needs very strong financial intermediaries for economic growth.

With regard to Table 1, the results of analysis show that the first hypothesis is accepted at 95\% significant level. According to table No. 3 the majority of respondents believe that consulting with financial intermediaries associate to financial structure at the levels of 'moderate' and 'very'. As shown in table No 2, $55 \%$ of respondents believe that consulting with financial intermediaries affects to financial structure of quoted firms in Tehran Stock Exchange. Only 17.5\% of respondents believe that consulting with financial intermediaries has low affect on firm financial structure. Furthermore, based on TSE annual report (2006) the number of firms that use the financial intermediaries services are boosting and those firms has better financial performance rather than other firms. It is safe to say, financial intermediaries consulting plays effective rule in Iranian capital market.

Table 1: Summary of testing hypotheses

\begin{tabular}{|c|c|c|c||}
\hline Independent variable & hypothesis(1) & hypothesis(2) & hypothesis(3) \\
\hline Dependent Variable & Financial Structure & Value of Share & Risk of Investment \\
\hline intermediaries & $\begin{array}{c}\text { Effectiveness role of } \\
\text { financial management } \\
\text { intermediaries }\end{array}$ & $\begin{array}{c}\text { Financial Intermediaries } \\
\text { expert }\end{array}$ \\
\hline Degree of freedom & 14 & 99 & 99 \\
\hline Chi-Square & 32.62 & 17 & 17 \\
\hline Significant level & $95 \%$ & 63.29 & 84.25 \\
\hline Conclusion & Confirm & $99 \%$ & Confirm \\
\hline
\end{tabular}

With reference to analysis of second hypothesis, finding shows that the hypothesis is accepted at $99 \%$ level. In other words, $54 \%$ of respondents believe that Effectiveness role of financial management intermediaries lead to increase share value of firms. In contrast, merely $16.5 \%$ of respondents support this idea that, financial management intermediaries have low affective role on increasing of share value. 
Table 2: Results of hypotheses

\begin{tabular}{||c|c|c|c||}
\hline Effect & Hypothesis(1) & Hypothesis(2) & Hypothesis(3) \\
\hline & Percent & Percent & Percent \\
\hline Very less & 4 & 4 & 5 \\
\hline Less & 13.5 & 12.5 & 13 \\
\hline Moderate & 27.5 & 29.5 & 26 \\
\hline Very & 20.0 & 28.5 & 33 \\
\hline Very much & 35.0 & 25.5 & 100 \\
\hline Total & 100 & 100 & \\
\hline
\end{tabular}

Table 3: Results of questions

\begin{tabular}{|c|c|c|c|c|c||}
\hline Questions & Very less & Less & Moderate & Very & Very much \\
\hline 1 & 4.5 & 17.9 & 22.4 & 40.3 & 14.9 \\
\hline 2 & 1.5 & 14.9 & 53.7 & 29.9 & 0.0 \\
\hline 3 & 1.5 & 6.0 & 29.9 & 37.3 & 25.4 \\
\hline 4 & 0.0 & 16.4 & 35.8 & 37.3 & 10.4 \\
\hline 5 & 3.0 & 19.4 & 47.8 & 25.4 & 4.5 \\
\hline 6 & 4.5 & 9.0 & 34.3 & 32.8 & 19.4 \\
\hline 7 & 4.5 & 20.9 & 34.3 & 32.8 & 7.5 \\
\hline 8 & 1.5 & 10.4 & 28.4 & 43.3 & 16.4 \\
\hline 9 & 0.0 & 10.4 & 28.4 & 41.8 & 19.4 \\
\hline 10 & 3.0 & 6.0 & 37.3 & 41.8 & 11.9 \\
\hline 11 & 1.5 & 10.4 & 28.4 & 44.8 & 14.9 \\
\hline 12 & 4.5 & 11.9 & 37.3 & 35.8 & 10.4 \\
\hline 13 & 0.0 & 9.0 & 26.9 & 46.3 & 17.9 \\
\hline 14 & 1.5 & 6.0 & 32.8 & 40.3 & 19.4 \\
\hline 15 & 10.4 & 9.0 & 29.9 & 44.8 & 6.0 \\
\hline
\end{tabular}

(Percentage of survey responding)

With regard to questionnaire majority of respondents assert that those factors have adequate effect on share value which table 3 also shows. 
The results of third hypothesis show that this hypothesis is also accepted at the $99 \%$ level. According to table 2 only $18 \%$ of respondents believe that there is no use of Financial Intermediaries experts to reduce risk of investment. However, other participants are thinking in the other way. With regard to table No. 3 about $60 \%$ of respondents strongly agree that financial intermediaries can help to reduce investment risk. According to statement no 13, around 64\% strongly agreed that financial intermediaries' guidance leads to reduce firm portfolio risk.

\section{Conclusion}

It is found that financial development reduces macroeconomic volatility. Financial intermediaries and the legal system provide an alternative way of accomplishing some of the key functions that the firm accomplishes internally: the mobilization of resources for investment, the monitoring of performance, and resolution of conflicts among different parties. There may also be another opposing effect at work. Large firms are also subject to agency problems. Their size and complexity makes expropriation by firms' insiders difficult to monitor and control by outside investors. Thus, investors in large firms may require strong financial institutions and effective legal systems to control expropriation by corporate insiders. In this research the authors come to the conclusion that although Iranian financial intermediaries play important role in capital market, the condition of Tehran Stock Market is not suitable. Iranian business sector at first should encourage and establish more financial intermediaries. Secondly, opportunities should be provided to establish foreign financial intermediaries for practicing in Iranian business sectors; as they have long experiences and they may also give new ideas to Iranian business sectors.

\section{REFERENCES}

Allen and Ndikumana (1998), 'Financial Intermediation and Economic Growth in Southern Africa', Journal of Money, Vol. 12, No. 1, pp: 220-242.

Atje, R.and B, Jovanovic (1993) 'Stock markets and development', European Economic Review, Vol. 37, pp: $632-640$.

Bencivenga, V. and B. Smith (1991) 'Financial Intermediation and Endogenous Growth,' Review of Economic Studies, Vol.58, No.2, pp: 195-209.

Bencivenga, V. and B. Smith (1992), 'Deficits, Inflation, and the Banking System in Developing Countries: The Optimal Degree of Financial Repression', Oxford Economic Papers, Vol.44, No.4, pp:: 767-790.

Bencivenga, V., and B. Smith (1993), 'Some Consequences of Credit Rationing in an Endogenous Growth Model', Journal of Economic Dynamics and Control, Vol.17, No. (1-2), pp: 97-122. 
Berthelemy, J. and A. Varoudakis(1995), 'Thresholds in Financial Development and Economic Growth’ The Manchester School of Economic and Social Studies, Vol. 63 (Supplement), pp: $70-84$.

Berthelemy, J., and A. Varoudakis (1997), 'Models of Financial Development and Growth.' In N. Hermes and R. Lensink, eds., Financial Development and Economic Growth: Theory and Experiences from Developing Countries, New York: Rutledge: 7-34.

Berthelemy, J.C. and Varoudakis (1996), Economic Growth, Convergence Clubs and the Role of Financial Development," Oxford Economic Papers, Vol. 48, No. 2, pp. 300-328.

Boyd, J. H. and B. D, Smith, (1998) 'The Evolution of Debt and Equity Markets in Economic Development', Economic Theory, Vol. 12, pp: 519-560.

Buffie, E.F. (1984) 'Financial Repression, the New Structuralists, and Stabilisation Policy in Semi-Industrialised Economies', Journal of Development Economics, Vol. 14, No.3, pp: 305-322.

Carranza, L (2000), 'Explaining Economic Growth with Imperfect Credit Markets', IMF

Working Paper No. 00/193.

Diamond, D., (1984), 'Financial Intermediation and Delegated Monitoring', Review of Economic Studies, Vol. 51, pp: 393-414.

Edgeworth, F.Y (1888), 'The Mathematical Theory of Banking', Journal of Royal Statistical Society, Part. 1, pp:11-127.

Edwards, S. and C. A, Vegh, (1998) 'Banks and Macroeconomic Disturbances under Predetermined Exchange Rates', NBER Working Paper No. 5977.

Goldsmith, R. W. (1969), Financial Structure and Development, New Haven, Connecticut: Yale University Press.

Greenwald, B., J. Stiglitz and A. Weiss (1984), 'Informational Imperfections in the Capital Market and Macroeconomic Fluctuations,' American Economic Review, 74(2): 194-200.

Greenwood, J. and B. Jovanovic (1990), 'Financial Development, Growth, and the Distribution of Income,' Journal of Political Economy, Vol. 98, No.5, pp: 10-76.

Gurley, J. G and E. S, Shaw (1960), Money and Theory of Finance, the Booking Institution, Washington, D.C.

Harris, J., F. Schiantarelli and M. Siregar(1994), 'The Effect of Financial Liberalization on the Capital Structure and Investment Decisions of Indonesian Manufacturing Establishments', The World Bank Economic Review, Vol. 8, No.1, pp: 17-47.

Khan, M. and A. Senhadji (2000), 'Financial Development and Economic Growth: An Overview' IMF Working Paper No. 00/209.

Kyle, A., (1985), 'Continuous Auctions and Insider Trading', Econometrica, Vol. 53, pp: 1315-1335.

Leland, H.E., and D.H. Pyle, (1977), 'Information Asymmetries, Financial Structure and Financial Intermediation', Journal of Finance, Vol. 32, pp. 371-387.

Levine, R (1991) 'Stock Markets, Growth, and Tax Policy', Journal of Finance, Vol. 46, No.4, pp: $1445-1465$.

Levine, R (1997b), 'Financial Sector Policies.' In N. Hermes and R Lensink, eds. Financial Development and Economic Growth: Theory and Experiences from Developing Countries. New York: Rutledge, pp: 161-191.

Levine, R. (1999). 'Bank-Based and Market-Based Financial Systems: Cross-Country Comparisons,' World Bank Working, Paper No. 2143.

Levine, R. and S, Zervos, (1998), 'Stock Markets, Banks, and Economic Growth', American Economic Review, Vol. 88, No. 3, pp: 537-558.

McKinnon, R. (1973), Money and Capital in Economic Development, Brookings Institution, Washington DC. 
Mowery, D.C., (1998), 'The Changing Structure of the US National Innovation System: Implications for International Conflict and Cooperation in R\&D Policy', Research Policy, Vol. 27, pp: 639-654.

Saint-Paul, G (1992), 'Technological Choice, Financial Markets, and Economic Development' European Economic Review, Vol.36, No.4, pp: 763-81, 1992.

Schumpeter, J. (1912), the Theory of Economic Development, Cambridge, Mass.: Harvard University Press.

Shaw, E. (1973), Financial Deepening in Economic Development, New York: Oxford University Press.

Tsuru, K. (2000), 'Finance and Growth: Some Theoretical Considerations, and a Review of the Empirical Literature' OECD Economics Department Working Paper No. 228. 